Expl Agric. (1993), volume 29; pp. 9-19 (C) 1993 Cambridge University Press

Printed in Great Britain

\title{
ADAPTATION OF LENTIL TO THE MEDITERRANEAN ENVIRONMENT. I. FACTORS AFFECTING YIELD UNDER DROUGHT CONDITIONS
}

\author{
By S. N. SILIM $\uparrow$, M. C. SAXENA and W. ERSKINE \\ International Center for Agricultural Research in the Dry Areas (ICARDA), \\ PO Box 5466, Aleppo, Syria \\ (Accepted 27 January 1992)
}

\begin{abstract}
SUMMARY
Lentil frequently suffers from drought stress towards the end of the growing season in rainfed Mediterranean farming systems. This study aimed to quantify the contribution of yield potential under irrigated conditions and of drought escape to the adaptation of lentils to drought, and to identify traits of value in selection for adaptation to a rain-fed Mediterranean environment. Twenty-five diverse lentil lines were sown under both irrigated and rainfed conditions in the 1987/88 and 1988/89 seasons in northern Syria. In 1987/88 the total seasonal rainfall was $403 \mathrm{~mm}$ and average rainfed biomass and seed yields were 5.0 and $1.8 \mathrm{t} \mathrm{ha} \mathrm{h}^{-1}$, respectively. In contrast, in 1988/89 the total season rainfall was $180 \mathrm{~mm}$ and average biomass and seed yields were only 0.67 and $0.12 \mathrm{t} \mathrm{ha}^{-1}$, respectively. Early vigour (estimated as a visual score) and percentage ground cover were strongly associated with final biomass, and were of value in predicting economic yield (seed + straw). Early maturity was correlated with seed yield. In the dry season $1988 / 89,49 \%$ of the variation in seed yield among lines was accounted for by variation in flowering time. Drought escape was clearly the key response to drought. For severely drought-prone areas, selection for early flowering is therefore required. Variation in flowering time and seed yield under irrigated conditions accounted for $62 \%$ of seed yield variation under drought stress.
\end{abstract}

Adaptación de la lenteja a la sequía

\section{RESUMEN}

En los sistemas agrícolas del Mediterráneo con riego por precipitaciones la lenteja con frecuencia sufre por falta de agua hacia el fin de la esactión de crecimiento. El objetivo de esté estudio radica en cuantificar la contribución del potencial de rendimiento bajo condiciones de irrigación y de escape a la sequía, a la adaptación de la lenteja a la sequía; y en identificar rasgos de valor en la selección para la adaptación al àmbiente Mediterráneo con riego por precipitaciones. En el norte de Siria se sembraron veinticinco variedades diferentes de lenteja, tanto bajo condiciones de riego por precipitaciones como por irrigación, durante las temporadas $1987 / 88$ y 1988/89. En 1987/88 el total de precipitaciones de estación fue de $403 \mathrm{~mm}$, y el promedio de biomasa y rendimiento de semilla con riego por precipitaciones fue de 5,0 y $1,8 \mathrm{t} \mathrm{ha}^{-1}$, respectivamente. En 1988/89, por el contrario, el total de precipitaciones de estación fue de 180 mm y el promedio de biomasa y rendimiento de semilla sólo fue de 0,67 y $0,12 \mathrm{t} \mathrm{ha}^{-1}$, respectivamente. El vigor temprano (estimado como cómputo visual) y el porcentaje de cobertura del suelo estuvieron altamente relacionados con la biomasa final, y resultaron valiosos para pronosticar el rendimiento económico (semilla + paja). La madurez temprana estuvo correlacionada con el rendimiento de semilla. En la estación seca de 1988/89, un 49\% de

$\dagger$ Present address: International Crops Research Institute for the Semi-Arid Tropics (ICRISAT), Patancheru PO, AP 502 324, India. 
la variación en el rendimiento de semilla se debió a la variación en la época de florecimiento. El escape a la sequía fue, con claridad, la respuesta clave para la sequía. Por lo tanto, para zonas con tendencia a severa sequía, es indispensable elegir variedades de florecimiento temprano. La variación en el momento de floración y en el rendimiento de semilla fue responsable de un $62 \%$ de la variación en el rendimiento de semilla con falta de agua.

\section{INTRODUCTION}

Rain falls during the winter months at low to moderate elevations $(0-1000 \mathrm{~m}$ altitude) in West Asia and North Africa (WANA). Lentil (Lens culinaris Medikus) is sown between the $300-400 \mathrm{~mm}$ rainfall isohyets in winter, generally in December and January, and harvested in May. The early stage of vegetative growth occurs in a period of increasing rainfall, low evaporative demand and increasing soil water content, but growth is restricted by low radiation and temperature (Smith and Harris, 1981). From March until maturity, the crop experiences increasingly strong radiation and a rapid rise in temperature, which causes the rate of leaf area development and evapotranspiration to increase. This period of high evaporative demand, which in lentil occurs at flowering, coincides with the end of the rainy period when residual soil moisture is rarely adequate to meet the evaporative demand. The lentil crop therefore experiences considerable drought stress during the reproductive growth phase and produces poor yields.

One of the principal objectives of lentil improvement research at the International Center for Agricultural Research in the Dry Areas (ICARDA) is the development of cultivars that produce high and stable yields in environments where drought stress is a major production constraint (ICARDA, 1989a). Acevedo and Ceccarelli (1989) suggested that the breeding of better adapted and higher yielding barley cultivars would be more effective if attributes that confer drought resistance were used as selection criteria. Using the black box approach of Fischer (1981), Bidinger et al. (1987a and b) analysed the performance of sets of pearl millet genotypes and the effects of different traits on their performance under drought stress; a drought resistance index (DRI) was used to test the response of individual cultivars to stress.

The experiments reported here were designed to: examine the response of a number of lentil lines to drought; estimate the contribution of yield potential under irrigated conditions and the contribution of drought escape to adaptation to drought; and determine the traits that contribute to high and stable yields in the drought stressed environments of West Asia and North Africa.

\section{MATERIALS AND METHODS}

The experiments were conducted at ICARDA's sub-research station at Breda, northern Syria $\left(35^{\circ} 56^{\prime} \mathrm{N}, 37^{\circ} 10^{\prime} \mathrm{E}\right)$ on a Typic Calciorthid soil during the $1987 / 88$ and 1988/89 cropping seasons. The land was ploughed and cultivated and a basal dose of $22 \mathrm{~kg} \mathrm{P} \mathrm{ha}^{-1}$ was incorporated. Twenty-five diverse lines of lentil, differing 
in origin, phenology and seed mass, were sown on 7 December 1987 and 27 November 1988. The lines included landraces from seven countries and a wide range of selections from crosses made at ICARDA. The experiment was laid out in a randomized block design with four replications. Each plot was $2.7 \mathrm{~m}$ wide and $18.0 \mathrm{~m}$ long. The inter-row spacing was $0.225 \mathrm{~m}$ and the sowing rate 270 seeds $\mathrm{m}^{-2}$. An irrigation treatment was superimposed on the plots by means of a linesource sprinkler irrigation system (Hanks et al., 1976), with the area nearest the line-source receiving most irrigation and the area furthest away from the linesource depending entirely on rainfall. Access tubes, each $1.8 \mathrm{~m}$ long, were installed in the rainfed and irrigated regimes in each plot. Soil water content was monitored regularly using a modified version of the Wallingford neutron probe (Bell, 1969). Readings were taken at $0.15 \mathrm{~m}$ depth intervals throughout the soil profile. Soil water deficit and irrigation need in the irrigated treatment were calculated from the neutron probe data. The aim was to keep the deficit below 40 $\mathrm{mm}$ in the wettest treatment, that is, at a level that would be unlikely to affect most field crops (Penman, 1962).

Repeated records were made in the unirrigated treatment of vigour, as dry matter $\mathrm{m}^{-2}$ and as a visual score on a $1-5$ scale $(1=$ least vigorous and $5=$ most vigorous), leaf colour on a scale of $1-5(1=$ dark green and $5=$ light green), percentage ground cover (visually estimated); and phenology.

At maturity, plants were harvested from both treatment areas (wet and rainfed) after discarding border areas. The harvested plants were sun dried to a seed moisture content of about $8 \%$ and subsequently weighed, threshed and cleaned, and seed weight obtained.

\section{RESULTS}

The results reported here mainly concern the unirrigated treatment. Results from the irrigated treatments are discussed in a companion paper (Silim et al., 1993).

\section{Weather conditions and irrigation}

The two seasons of the experiment provided a striking contrast, with a total annual precipitation of $400.3 \mathrm{~mm}$ in the $1987 / 88$ season (the wettest since 1940 / 41) but only $180 \mathrm{~mm}$ in the $1988 / 89$ season, compared with the long-term average for Breda of $281 \mathrm{~mm}$.

Temperatures throughout the 1987/88 cropping season were close to the longterm average, with less than 20 frost days (ICARDA, 1989b). In the 1988/89 season, air temperatures were abnormally low during the December-March period, with more frost days than the long-term average.

In 1987/88, the difference in the moisture supply between the unirrigated and irrigated treatments was small because of the plentiful rainfall. In the 1988/89 season, the high frequency of windy days meant that the water deficit could not always be maintained below $40 \mathrm{~mm}$ in the well irrigated treatment. 
Table 1. Pedigree, origin, seed size and number of days from sowing to different stages of development in the lentil lines sozen in the $1988 / 89$ season

\begin{tabular}{lllllll}
\hline Line & Name/selection & Origin & Seed size & Emergence & Flowering & Maturity \\
\hline ILL 481 & - & Lebanon & $\mathrm{Mi}$ & 17 & 128 & 162 \\
ILL 1939 & - & Morocco & $\mathrm{Mi}$ & 16 & 123 & 156 \\
ILL 2126 & Kurdi 1 & Syria & $\mathrm{Ma}$ & 18 & 125 & 162 \\
ILL 4349 & Laird & Canada & $\mathrm{Ma}$ & 18 & 128 & 162 \\
ILL 4354 & - & Jordan & $\mathrm{Mi}$ /Ma & 16 & 114 & 150 \\
ILL 4400 & Local large & Syria & $\mathrm{Ma}$ & 18 & 120 & 155 \\
ILL 4401 & Local small & Syria & $\mathrm{Mi}$ & 18 & 120 & 150 \\
ILL 4403 & - & Pakistan & $\mathrm{Mi}$ & 18 & 114 & 138 \\
ILL 5582 & 78S 26002 & Jordan & $\mathrm{Ma}$ & 18 & 114 & 150 \\
ILL 5588 & 78S 26013 & Jordan & $\mathrm{Mi}$ & 16 & 110 & 148 \\
ILL 5604 & 78S 26052 & Turkey & $\mathrm{Mi}$ & 17 & 123 & 152 \\
ILL 5715 & FLIP84-44L & ICARDA & $\mathrm{Mi}$ & 17 & 128 & 156 \\
ILL 5754 & FLIP84-48L & ICARDA & $\mathrm{Ma}$ & 16 & 123 & 155 \\
ILL 5775 & FLIP84-105L & ICARDA & $\mathrm{Mi}$ & 18 & 120 & 152 \\
ILL 5782 & FLIP84-112L & ICARDA & $\mathrm{Mi}$ & 18 & 114 & 150 \\
ILL 5860 & FLIP85-22L & ICARDA & $\mathrm{Mi}$ & 17 & 118 & 148 \\
ILL 5863 & FLIP85-25L & ICARDA & $\mathrm{Mi}$ & 18 & 120 & 148 \\
ILL 5989 & FLIP86-3L & ICARDA & $\mathrm{Ma}$ & 16 & 114 & 148 \\
ILL 5991 & FLIP86-5L & ICARDA & $\mathrm{Ma}$ & 16 & 114 & 148 \\
ILL 5994 & FLIP86-8L & ICARDA & $\mathrm{Ma}$ & 18 & 118 & 152 \\
ILL 6004 & FLIP86-18L & ICARDA & $\mathrm{Ma}$ & 15 & 114 & 138 \\
ILL 6011 & FLIP86-25L & ICARDA & $\mathrm{Ma}$ & 17 & 118 & 148 \\
ILL 6024 & FLIP86-38L & ICARDA & $\mathrm{Mi}$ & 17 & 118 & 148 \\
ILL 6035 & FLIP86-49L & ICARDA & $\mathrm{Ma}$ & 15 & 110 & 138 \\
ILL 6049 & FLIP86-63L & ICARDA & $\mathrm{Mi}$ & 18 & 118 & 148 \\
\hline
\end{tabular}

$\lceil\mathrm{Ma}=$ macrosperma, $\mathrm{Mi}=$ microsperma

\section{Crop development}

The time taken for the crop to reach different phenological stages is given for 1988/89 in Table 1. Time to flowering ranged from 110 to 128 days and time to maturity from 138 to 162 days.

Vigour measured as dry matter $\mathrm{m}^{-2}$ was highly correlated with the visual score for vigour at each phenological stage ( $\mathrm{r}$ values ranged from 0.89 to 0.95 ), therefore only visual scores are reported here. In both 1987/88 and 1988/89, there were significant variations in early vigour among genotypes, the most vigorous lines in both seasons being ILL 4349, ILL 5582, ILL 5989, ILL 6004, ILL 6011 and ILL 6035. Similarly, there were significant variations among lines in percentage ground cover. In 1987/88, the maximum percentage ground cover varied from 87.5 to $100 \%$, but in $1988 / 89$ the range was less, $41-57 \%$. The build-up in ground cover was fastest in the most vigorous lines.

Differences in leaf colour were recorded during early vegetative growth. For example, in both seasons, ILL 6004 and ILL 6035 were light green and ILL 4400, ILL 4401 and ILL 6049 were dark green. With a rise in temperature most genotypes that were dark green gradually changed to light green. 
Table 2. Correlations $(r)$ between various traits in rainfed lentil on four dates in the $1987 / 88$ and $1988 / 89$ seasons

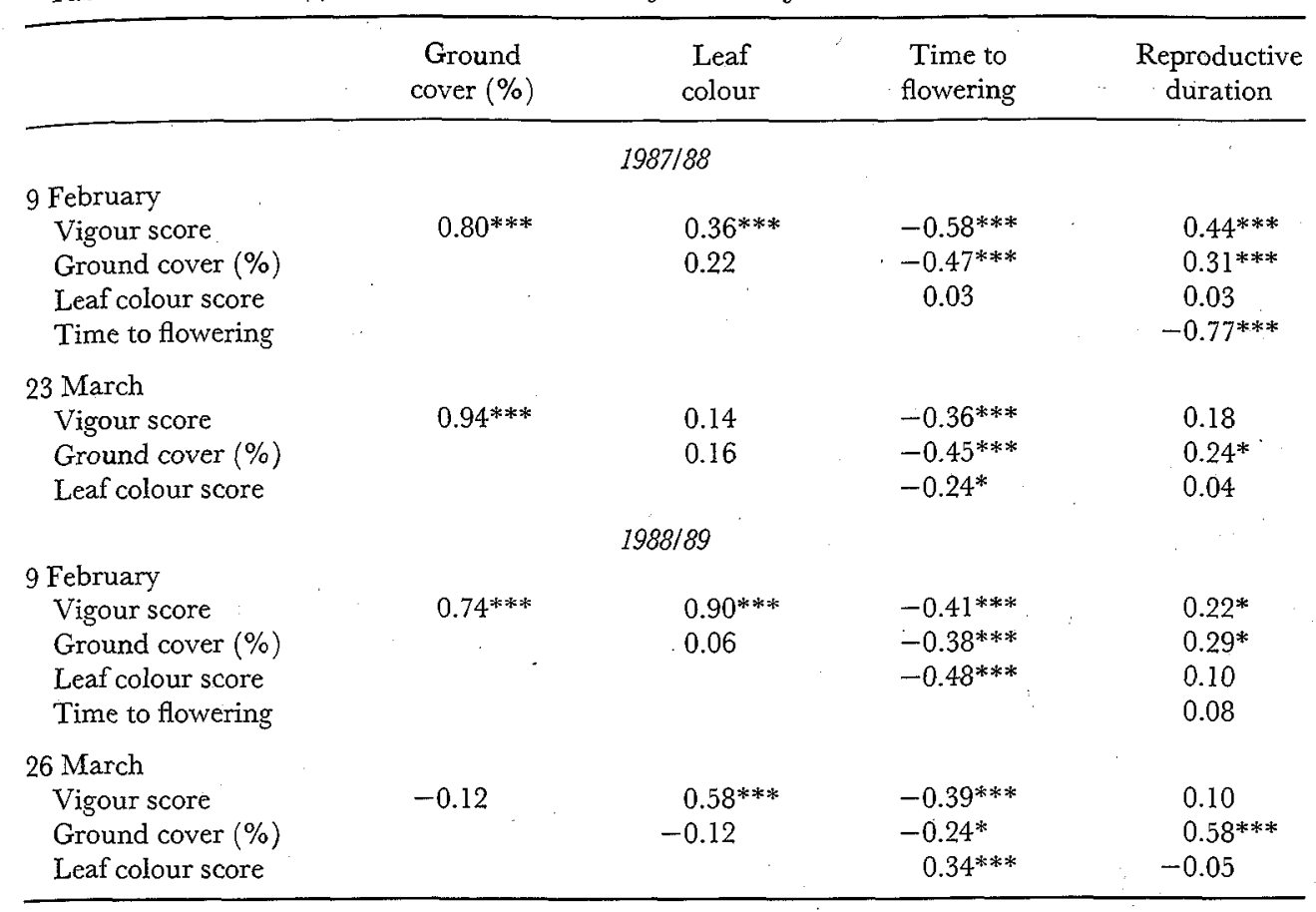

* and ${ }^{* * *}$ denote significance at $\mathrm{P}<0.05$ and $\mathrm{P}<0.001$, respectively.

Correlations between the score for vigour, percentage ground cover, and the score for leaf colour are given in Table 2 . Lines that exhibited early vigour also achieved early ground cover, were early flowering and were light green in colour during vegetative growth. The association between early ground cover and light green colour was significant only in 1987/88.

\section{Yields}

The rainfed biomass (total dry matter in above-ground parts) in 1987/88 was high, averaging $5.0 \mathrm{t} \mathrm{ha}^{-1}$, which compared with a mean biomass of $0.67 \mathrm{tha}^{-1}$ in 1988/89. Biomass differed significantly among lines (Table 3 ). The rainfed seed yields in the wet $1987 / 88$ season ranged from 1.02 to $2.19 \mathrm{t} \mathrm{ha}^{-1}$, with an overall mean of $1.81 \mathrm{tha}^{-1}$. In the 1988/89 dry season, the seed yield of unirrigated crops varied from 0.06 to $0.32 \mathrm{t} \mathrm{ha}^{-1}$, with an overall mean of $0.18 \mathrm{tha}^{-1}$. The harvest index was larger in the wet $1987 / 88$ season, with a mean of 0.36 compared with 0.26 in the dry $1988 / 89$ season (Table 3 ). The harvest index varied significantly between lines.

Factors influencing biomass and seed yield in unirrigated lentils

Total recoverable biomass is an important characteristic of lentils in WANA, since the seed is used for human consumption and the straw for animal feed (Silim 
Table 3. Biomass (total dry matter) and seed yield $\left(\mathrm{t} \mathrm{ha} \mathrm{a}^{-1}\right)$ and harvest index of unirrigated lentil lines at Breda, northern Syria, during the 1987/88 and 1988/89 seasons, and drought response index (DRI) for biomass and seed yields in 25 lentil lines in the 1988/89 season

\begin{tabular}{|c|c|c|c|c|c|c|c|c|}
\hline \multirow[b]{2}{*}{ Line } & \multicolumn{3}{|c|}{$1987 / 88$} & \multicolumn{3}{|c|}{$1988 / 89$} & \multicolumn{2}{|c|}{$\begin{array}{l}\text { Drought } \\
\text { response index }\end{array}$} \\
\hline & Biomass & $\begin{array}{l}\text { Seed } \\
\text { yield }\end{array}$ & $\begin{array}{l}\text { Harvest } \\
\text { index }\end{array}$ & Biomass & $\begin{array}{l}\text { Seed } \\
\text { yield }\end{array}$ & $\begin{array}{l}\text { Harvest } \\
\text { index }\end{array}$ & Biomass & $\begin{array}{l}\text { Seed } \\
\text { yield }\end{array}$ \\
\hline ILL 481 & 3.56 & 1.10 & 0.30 & 0.60 & 0.06 & 0.11 & 0.25 & -0.34 \\
\hline ILL 1939 & 5.19 & 1.96 & 0.38 & 0.61 & 0.16 & 0.25 & -0.21 & 0.37 \\
\hline ILL 2126 & 4.10 & 1.39 & 0.34 & 0.66 & 0.12 & 0.18 & 0.58 & 0.14 \\
\hline ILL 4349 & 4.95 & 1.02 & 0.21 & 0.63 & 0.09 & 0.15 & 0.09 & -0.61 \\
\hline ILL 4354 & 4.30 & 1.76 & 0.41 & 0.71 & 0.20 & 0.28 & 0.05 & -1.06 \\
\hline ILL 4400 & 3.61 & 1.41 & 0.39 & 0.59 & 0.08 & 0.14 & -0.56 & $-1.78^{*}$ \\
\hline ILL 4401 & 6.05 & 1.95 & 0.32 & 0.51 & 0.16 & 0.30 & $-1.32^{*}$ & -0.34 \\
\hline ILL 4403 & 4.20 & 1.73 & 0.42 & 0.50 & 0.17 & 0.35 & $-2.13^{*}$ & -0.82 \\
\hline ILL 5582 & 6.27 & 2.04 & 0.33 & 0.68 & 0.17 & 0.24 & -0.26 & -1.24 \\
\hline ILL 5586 & 5.35 & 2.12 & 0.40 & 0.62 & 0.16 & 0.26 & -0.65 & -1.01 \\
\hline ILL 5604 & 5.94 & 2.16 & 0.36 & 0.59 & 0.13 & 0.22 & -0.38 & -0.35 \\
\hline ILL 5715 & 5.42 & 1.85 & 0.34 & 0.64 & 0.15 & 0.23 & 0.38 & 1.20 \\
\hline ILL 5754 & 3.37 & 1.11 & 0.34 & 0.69 & 0.19 & 0.28 & 0.42 & 0.91 \\
\hline ILL 5775 & 5.55 & 1.92 & 0.35 & 0.78 & 0.19 & 0.24 & 1.22 & 1.02 \\
\hline ILL 5782 & 4.00 & 1.67 & 0.42 & 0.71 & 0.17 & 0.25 & 0.16 & -0.74 \\
\hline ILL 5860 & 5.56 & 2.03 & 0.36 & 0.62 & 0.19 & 0.30 & -0.74 & -0.88 \\
\hline ILL 5863 & 4.84 & 1.65 & 0.34 & 0.68 & 0.21 & 0.30 & 0.08 & 0.60 \\
\hline ILL 5989 & 5.59 & 1.98 & 0.36 & 0.74 & 0.22 & 0.29 & 0.27 & -0.06 \\
\hline ILL 5991 & 5.48 & 2.02 & 0.39 & 0.79 & 0.22 & 0.28 & 0.68 & -0.07 \\
\hline ILL 5994 & 5.24 & 1.82 & 0.34 & 0.73 & 0.22 & 0.29 & 0.45 & 0.73 \\
\hline ILL 6004 & 5.78 & 2.19 & 0.38 & 0.81 & 0.28 & 0.35 & 0.94 & 1.28 \\
\hline ILL 6011 & 5.35 & 2.14 & 0.40 & 0.88 & 0.26 & 0.29 & $1.68^{*}$ & 1.10 \\
\hline ILL 6024 & 4.26 & 1.97 & 0.46 & 0.50 & 0.14 & 0.27 & $-1.98^{*}$ & -0.45 \\
\hline ILL 6035 & 5.37 & 1.87 & 0.35 & 0.90 & 0.32 & 0.35 & $1.76^{*}$ & $2.23^{*}$ \\
\hline ILL 6049 & 5.15 & 1.94 & 0.38 & 0.61 & 0.20 & 0.33 & -0.68 & 0.17 \\
\hline SE & 0.36 & 0.14 & & 0.05 & 0.06 & & & \\
\hline
\end{tabular}

*denotes significance at $\mathrm{P}<0.01$.

et al., 1989). Studies on pea (Hedley and Ambrose, 1981; Silim et al., 1985) and chickpea (Saxena et al., 1990) have shown that high dry matter production is one of the major prerequisites for high seed yield. Therefore, in the present investigation, the analyses of yield in the rainfed treatment were conducted by considering correlations of rainfed biomass and seed yield with growth traits and phenology and, in 1988/89, also with irrigated biomass.

Crop vigour and percentage ground cover were strongly correlated with final biomass in both seasons (Table 4). However, final biomass was only correlated with leaf colour during early vegetative growth in 1988/89. During the wet season (1987/88), the number of days to maturity and the length of the reproductive period were negatively correlated with biomass.

Crop vigour and percentage ground cover were correlated with seed yield in 
Table 4. Correlations ( $r$ ) of rainfed biomass and seed yield with other traits at Breda, North Syria, 1987/88 and 1988/89

\begin{tabular}{|c|c|c|c|c|c|c|}
\hline & \multicolumn{3}{|c|}{$1987 / 88$} & \multicolumn{3}{|c|}{$1988 / 89$} \\
\hline & Date & Biomass & Seed yield & Date & Biomass & Seed yield \\
\hline Vigour & $\begin{array}{l}27 \mathrm{Feb} . \\
23 \mathrm{Mar} . \\
15 \mathrm{Apr} .\end{array}$ & $\begin{array}{l}0.37 * * * \\
0.34 * * * \\
0.38 * * *\end{array}$ & $\begin{array}{l}0.20^{*} \\
0.24^{*} \\
0.29^{* *}\end{array}$ & $\begin{array}{l}7 \text { Feb. } \\
2 \text { Mar. } \\
26 \text { Mar. }\end{array}$ & $\begin{array}{l}0.32^{* *} \\
0.47^{* * * *} \\
0.37^{* * *}\end{array}$ & $\begin{array}{l}0.26 * * \\
0.34 * * * \\
0.29 * * *\end{array}$ \\
\hline Ground cover $(\%)$ & $\begin{array}{l}17 \text { Feb. } \\
13 \text { Mar. } \\
4 \text { Apr. }\end{array}$ & $\begin{array}{l}0.25 * \\
0.34 * * * \\
0.54 * * *\end{array}$ & $\begin{array}{l}0.03 \\
0.17 \\
0.31^{* *}\end{array}$ & $\begin{array}{r}7 \text { Feb. } \\
2 \text { Mar. } \\
26 \text { Mar. }\end{array}$ & $\begin{array}{l}0.25^{*} \\
0.59^{* * *} \\
0.46^{* * *}\end{array}$ & $\begin{array}{l}0.25 * \\
0.54 * * * \\
0.48 * * *\end{array}$ \\
\hline Colour & $\begin{array}{l}17 \text { Feb. } \\
13 \text { Mar. }\end{array}$ & $\begin{array}{l}0.05 \\
0.06\end{array}$ & $\begin{array}{l}0.10 \\
0.16\end{array}$ & $\begin{array}{l}7 \mathrm{Feb} . \\
9 \mathrm{Mar} .\end{array}$ & $\begin{array}{l}0.32 * * \\
0.02\end{array}$ & $\begin{array}{l}0.27^{* *} \\
0.24^{*}\end{array}$ \\
\hline $\begin{array}{l}\text { Time to flowering } \\
\text { Time to maturity } \\
\text { Reproductive period } \\
\text { Rainfed biomass }\end{array}$ & & $\begin{array}{l}-0.04 \\
-0.48 * * * \\
-0.27 * *\end{array}$ & $\begin{array}{l}-0.17 \\
-0.34^{* * *} \\
-0.07 \\
0.78^{* * *}\end{array}$ & & $\begin{array}{r}0.24^{*} \\
-0.12 \\
-0.07\end{array}$ & $\begin{array}{r}-0.45^{* * * *} \\
-0.49^{* * *} \\
-0.27^{* *} \\
0.80^{* * *}\end{array}$ \\
\hline $\begin{array}{l}\text { Harvest index } \\
\text { Seed yield, irrigated } \\
\text { Biomass, irrigated }\end{array}$ & & -0.22 & $0.49^{* * *}$ & & $\begin{array}{l}0.51^{* * * *} \\
0.37^{* * *}\end{array}$ & $0.47^{* * *}$ \\
\hline
\end{tabular}

$*$,** and $* * *$ denote significance at $\mathrm{P}<0.05, \mathrm{P}<0.01$ and $\mathrm{P}<0.001$, respectively.

both years, particularly in the dry year, 1988/89, but leaf colour was only correlated with seed yield in the dry year. Time to flowering and maturity, and the length of the reproductive period, were negatively correlated with seed yield in the dry year (1988/89), but in the wet year (1987/88) only the correlation of time to maturity was significant. The negative relationships indicate that to produce a high seed yield, particularly in dry years, lines should flower early and have a brief seed-filling period (implying a high seed-filling rate). In both seasons a large biomass was the major determinant of seed yield. Potential seed yield (yield under irrigation) was also significantly correlated with rainfed seed yield.

\section{Drought response index}

The results from the 1988/89 experiment were used to calculate a drought response index (DRI) (Bidinger et al., 1987b) to quantify further the response of lentil genotypes to drought stress. The DRI was based on the residual variation in grain yield, after the effects of variability in time to flowering, and yield potential under irrigated conditions, were removed by multiple linear regression. For the identification of susceptible and tolerant genotypes, a threshold value of DRI = 1.30 was chosen, since this value selects genotypes in the top and bottom $10 \%$ of the normal distribution for yield under stress. A genotype was considered to have no (zero) response to stress if the predicted yield value in the drought stress treatment was within the limits of \pm 1.30 DRI. Positive or negative signs indicate that a genotype performed better or less well then expected. 
Table 5. Correlation ( $r$ ) of drought response index (DRI) for seed yield and biomass with some of the traits measured at Breda, $1988 / 89$

\begin{tabular}{lcc}
\hline & \multicolumn{2}{c}{ Drought response index } \\
\cline { 2 - 3 } & \multicolumn{1}{c}{ Biomass } & Seed yield \\
\hline Vigour on 2 March & $0.48^{* * *}$ & $0.33^{* *}$ \\
Ground cover (\%) on 2 March & $0.40^{* * *}$ & $0.45^{* * *}$ \\
Time to flowering & 0.14 & 0.07 \\
Biomass, rainfed & $0.63^{* * *}$ & \\
Biomass, irrigated & 0.01 & 0.10 \\
Seed yield, irrigated & -0.05 & -0.01 \\
\hline
\end{tabular}

** and *** denote significance at $\mathrm{P}<0.01$ and $\mathrm{P}<0.001$, respectively.

The results showed that time to flowering accounted for $49 \%$ of the variation in rainfed seed yield, and that time to flowering together with seed yield potential (yield under irrigation) accounted for $62 \%$ of the variation, the remainder being due to true drought response. However, total dry matter yield was less sensitive to time to flowering and yield potential, since both together accounted for only $14 \%$ of the variation.

Genotypic differences in DRI were significant only at the $10 \%$ level of probability (Table 3 ). Both seed yield and biomass of ILL 6035 showed tolerance to drought, but seed yield of ILL 4400 was drought susceptible. Biomass of ILL 6011 and ILL 6035 showed tolerance to drought but ILL 6024, ILL 4403 and ILL 4401 showed susceptibility.

Correlations of some of the traits with DRI were calculated to determine if they were advantageous under stress conditions (Table 5). DRI for biomass and seed yield were significantly correlated with vigour and percentage ground cover. DRI for seed yield was also significantly correlated with biomass at harvest under drought stress. This indicates that a rapid early increase in biomass, rapid development of ground cover and large biomass at harvest are good predictors of drought tolerance (Table 5).

\section{DISGUSSION}

There are two main approaches to the breeding of plants for drought-prone environments. The conventional approach is to use seed yield under drought stress as the main selection criterion. The second involves the identification and selection of morpho-physiological traits associated with drought tolerance, and is the one used here. It requires the cooperation of plant physiologists and plant breeders (Richards, 1982; Acevedo 1987; Clarke, 1987).

During the course of the experiments reported here, the seasons provided a useful contrast in rainfall, with the wet $1987 / 88$ season producing a seed yield ten 
times that of the following dry season. The relations between economic yield (biomass and seed yield) and other traits could therefore be divided into those that were exhibited clearly in both seasons and those that were environmentally dependent and only obvious in a dry or a wet season.

Environmentally independent associations with rainfed biomass included early vigour and percentage ground cover, and leaf colour and seed yield, as also found by Cooper et al. (1987). The increased production of total dry matter in plants with these characteristics was probably a result of efficient transpiration during the winter months (when temperature and atmospheric water saturation deficit were low), a reduction in evaporation from the soil surface, and increased availability of soil moisture for growth later in the season as a result of these two factors.

Breeders are often required to evaluate thousands of lines so the determination of early growth by destructive sampling is laborious, limiting the number of genotypes that can be handled. Gupta et al. (1986) reported a strong correlation between vegetative growth and biomass at harvest for oats and Takeda and Frey (1976) suggested that a crude measure of vegetative growth rates for oats could be obtained by dividing straw weight by days to heading. Wych et al. (1982), however, suggested that measuring vegetative growth rate on the basis of dry weight at anthesis would be more accurate. Our results show that visually assessed vigour was highly correlated with direct measurements of dry matter per unit area. A visual score that is simple to use enables a plant breeder rapidly to assess a large amount of genetic material.

In barley, a dark green colour early in the season, changing to pale green later in the season, was associated with early vigour (Acevedo, 1987). In lentil also, pale green colour early in the season was strongly correlated with vigour and, to a lesser extent, with biomass though this effect was only marked in the dry year (Tables 2 and 4). Acevedo (1987) reported that barley genotypes which were light green had a higher chlorophyll a/b ratio than those which were dark green. For lentil, no such information is yet available.

Lentil biomass was strongly correlated with seed yield in both the $1987 / 88$ and 1988/89 seasons. Silim et al. (1985) working with pea and Saxena et al. (1990) working with chickpea have shown that the attainment of a high biomass followed by high partitioning to the seeds is a major requirement of a high seed yield. Our study has shown that there is also a high correlation between seed yield and biomass in lentil. Takeda and Frey (1976) proposed that genetic improvement in the yield of oats would need to come via increased biomass. One of the major objectives of lentil improvement work at ICARDA is to increase biomass (ICARDA, 1989a).

There were clear associations between seed yield and early vigour, ground cover and leaf colour. These correlations were stronger in 1988/89 than in 1987/ 88, reflecting differences in rainfall between the two seasons. Light green colour during the early vegetative phase was associated with vigorous growth and the establishment of good ground cover, which in turn reduced evaporation from the 
soil surface, ensuring better soil moisture status at seed filling and hence better seed yield.

The environmentally-dependent characteristics that were associated with yield, displayed during the severe drought at the end of the 1988/89 season, are likely to be particularly important in the selection of drought tolerant lines. Correlations between phenology and seed yield were weak in the wet year, but accounted for $49 \%$ of the variation in seed yield in the dry year (Table 4). This is similar to the value of $57 \%$ reported for terminal stress in pearl millet by Bidinger et al. (1987a). In environments where there is no rain during the later part of the growing season early flowering tends to produce higher yields and greater yield stability than late flowering (Ludlow and Muchow, 1988). This is particularly true when the moisture supply is limited. Drought escape by early flowering was clearly the main factor accounting for good seed yield in some lentil lines under the conditions of severe drought at the end of the 1988/89 season. Selection for early flowering is therefore an appropriate strategy if the intention is to extend lentil cultivation to drier areas.

In seasons when rainfall is plentiful, short season varieties may leave potentially transpirable water in the soil at maturity and so incur a yield penalty, as shown for sorghum (Jordan et al., 1983) and soyabeans (Muchow and Sinclair, 1986). The weak association in the wet season (1987/88) between days to flowering and seed yield occurred because the late maturing lines were able to extract more water and so achieve better yields. A different selection strategy from that of selecting for early flowering is therefore required for areas receiving a mean annual rainfall of $300-400 \mathrm{~mm}$ (Silim et al., 1993).

Acknowledgements. We express our gratitude to Messrs N. Trabulsi and R. Ammaneh for their technical assistance.

\section{REFERENCES}

Acevedo, E. (1987). Assessing crop and plant attributes for cereal improvement in water limited environments. In Drought Tolerance in Winter Cereals, 303-320. (Eds J. P. Srivastava, E. Porceddu, E. Acevedo and S. Varma). Salisbury: John Wiley.

Acevedo, E. \& Ceccarelli, S. (1989). Role of physiologist-breeder in a breeding program for drought resistance conditions. In Drought Resistance in Cereals - Theory and Practice, 115-139. (Ed. F. W. G. Baker) Wallingford: Commonwealth Agricultural Bureaux International.

Bell, J. P. (1969). A new design principle for neutron soil moisture gauges: the 'Wallingford' neutron probe. Soil Science 108:160-164.

Bidinger, F. R., Mahalakshmi, V. \& Rao, G. D. P. (1987a). Assessment of drought resistance in pearl millet [Pennisetum americanum (L.) Leeke]. I. Factors affecting yield under stress. Australian Journal of Agricultural Research 38:37-48.

Bidinger, F. R., Mahalakshmi, V. \& Rao, G. D. P. (1987b). Assessment of drought resistance in pearl millet [Pennisetum americanum (L.) Leeke]. IT. Estimation of genotype response to stress. Australian Journal of Agricultural Research 38:49-59.

Clarke, J. M. (1987). Use of physiological and morphological traits in breeding programmes to improve drought resistance of cereals. In Drought Toterance in Winter Cereals, 171-190. (Eds J. P. Srivastava, E. Porceddu, E. Acevedo and S. Varma) Salisbury: John Wiley. 
Cooper, P. J. M., Gregory, P. J., Tully, D. \& Harris, H. C. (1987). Improving water use efficiency of annual crops in the rainfed farming systems of West Asia and North Africa. Experimental Agriculture 23:113-158.

Fischer, R. A. (1981). Optimizing the use of water and nitrogen through breeding crops. Plant and Soil 58:249-278.

Gupta, S. C., Cox, D. J. \& Frey, K. J. (1986). Association of two measures of vegetative growth rate with other traits in inter and intraspecific matings of oats. Theoretical and Applied Genetics 72:756-760.

Hanks, R. J., Keller, J., Rasmussen, V. P. \& Wilson, G. D. (1976). Line-source sprinkler for continuous variable irrigation-crop production studies. Soil Science Society of America Journal 40:426-429.

Hedley, C. L. \& Ambrose, M. J. (1981). Designing 'leafless' pea plants for improving yields of the dry pea crop. Advances in Agronomy 34:255-277.

ICARDA (International Center for Agricultural Research in the Dry Areas) (1989a). Food Legume Improvement Program Annual Report 1988, 63-65. Aleppo, Syria: ICARDA.

ICARDA (International Center for Agricultural Research in the Dry Areas) (1989b). Meteorological Reports for ICARDA Experiment Station in Syria: 1987/88 Season. Aleppo, Syria: ICARDA.

Jordan, W. R., Dugas, W. A. \& Shouse, P. J. (1983). Strategies for crop improvement for drought-prone regions. In Plant Production and Management under Drought Conditions, 281-299 (Eds J. F. Stone and W. O. Willis). Amsterdam: EIsevier.

Ludlow, M. M. \& Muchow, R. C. (1988). Critical evaluation of the possibilities for modifying crops for high production per unit precipitation. In Drought Research Priorities for Dryland. Tropics, 179-211 (Eds F. R. Bidinger and C. Johansen). Patancheru, AP: International Crops Research Institute for the Semi-Arid Tropics (ICRISAT).

Muchow, R. C. \& Sinclair, T. R. (1986). Water and nitrogen limitations in soybean grain production. II. Field and model analysis. Field Crops Research 15:143-156.

Penman, H. L. (1962). Woburn irrigation; 1951-59. II. Results for grass. Netherlands Journal of Agricultural Science 4:9-29.

Richards, R. A. (1982). Breeding and selecting for drought resistance in wheat. In Drought Resistance in Crops with Emphasis on Rice, 303-316. Los Banos: International Rice Research Institute (IRRI).

Saxena, M. C., Silim, S. N. \& Singh, K. B. (1990). Effect of supplementary irrigation during reproductive growth on winter and spring chickpea (Cicer arietinum) in a Mediterranean environment. Journal of Agricultural Science, Cambridge 114:285-294.

Silim, S. N., Hebblethwaite, P. D. \& Heath, M. G. (1985). Comparison of the effects of autumn and spring sowing date on growth and yield of combining peas. Journal of Agricultural Science, Cambridge 104:3546.

Silim, S. N., Saxena, M. C. \& Erskine, W. (1989). Effect of cutting height on the yield and straw quality of lentil and on a succeeding wheat crop. Field Crops Research 21:49-58.

Silim, S. N., Saxena, M. C. \& Erskine, W. (1993). Adaptation of lentil to the Mediterranean environment. II. Response to moisture supply. Experimental Agriculture 29:21-28.

Smith, R. G. G. \& Harris, H. C. (1981). Environmental resources and restraints to agricultural production in a Mediterranean-type environment. Plant and Soil 58:31-57.

Takeda, K. \& Frey, K.J. (1976). Contributions of vegetative growth rate and harvest index to grain yield of progenies from Avena sativa $\times$ A. sterilis crosses. Crops Science 16:817-821.

Wych, R. D., McGraw, R. L. \& Stuthman, D. D. (1982). Genotype $\times$ year interaction for length and rate of grain filling in oats. Crop Science 22:1025-1028. 